\title{
Indeks Malmquist: Studi Literatur dan Kajian Kinerja Perbankan Syariah
}

\section{Malmquist Index: Literature Riview and Study of Performance of Islamic Banking}

\author{
Supriyanto1) *, Khaira Amalia Fachrudin'2), Handy Octavianus ${ }^{3)}$, Juli Meliza4), \\ Dina Hastalona ${ }^{\text {5) }}$ \& Taslim Taslim ${ }^{6}$
}

1) Program Studi Administrasi Bisnis, Politeknik LP3I Medan, Indonesia

2) Program Studi Manajemen, Fakultas Ekonomi dan Bisnis, Universitas Sumatera Utara, Indonesia

3) Program Studi Doktor Imu Manajemen, Fakultas Ekonomi dan Bisnis, Universitas Sumatera Utara, Indonesia

4) Program Studi Manajemen, Sekolah Tinggi Ilmu Manajemen Sukma, Indonesia

5) Program Studi Manajemen, Sekolah Tinggi Ilmu Ekonomi ITMI, Indonesia

6) DPD MAPPI Sumut Aceh, Masyarakat Profesi Penilai Indonesia, Indonesia

Diterima: 18 Juni 2021; Direview: 02 Agustus 2021; Disetujui: 07 Oktober 2021

*Coresponding Email: faiziqameira@gmail.com

\begin{abstract}
Abstrak
Pengukuran kinerja Perbankan Syariah menggunakan Indeks Malmquist banyak dibahas oleh peneliti dari berbagai negara. Indeks Malmquist merupakan bagian metode Data Envelopment Analysis (DEA) yang digunakan untuk mengolah data non parametrik untuk mengukur perubahan produktivitas Decision Making Unit (DMU). Artikel ini bertujuan untuk melakukan studi literatur terhadap artikel ilmiah yang melakukan penelitian tentang Indeks Malmquist. Metode penelitian yang digunakan adalah Studi Pustaka, dimulai dengan menetapkan topik penelitian, kemudian melakukan kajian teoritis dan referensi yang terkait dengan penelitian yang dilakukan. Artikel yang ditelaah sebanyak 12 buah dengan kriteria yaitu literatur yang memiliki relevansi dengan tujuan penelitian, berupa Jurnal Ilmiah baik Jurnal Ilmiah Nasional, Jurnal Ilmiah Nasional Terakreditasi, Jurnal Ilmiah Internasional dan Jurnal Ilmiah Internasional Bereputasi. Hasil telaah mengungkapkan bahwa perbankan Syariah memiliki pertumbuhan produktivitas yang positif, berdasarkan kawasan Perbankan Syariah di luar Gulf Cooperation Council (GCC), memiliki kinerja yang lebih baik. Perbankan Syariah di Kawasan Asia Tenggara, yang diwakili oleh Malaysia dan Indonesia, secara bergantian, mendapat peringkat terbaik berdasarkan pemeringkatan oleh Islamic Finance Country Index (IFCI).
\end{abstract}

Kata Kunci: Indeks Malmquist; Kinerja Perbankan Syariah.

\begin{abstract}
Measurement of Islamic Banking Performance using the Malmquist Index has been widely discussed by researchers from various countries. The Malmquist index is part of the Data Envelopment Analysis (DEA) method which is used to process non-parametric data to measure the increase in Decision Making Unit (DMU) productivity. This article aims to conduct a literature study of scientific articles that research the Malmquist Index. The research method used is Literature Study, starting with determining the research topic, then conducting theoretical studies and references related to the research carried out. 12 articles have been reviewed with the criteria of literature that has relevance to the research objectives, in the form of Scientific Journals, both National Scientific Journals, Accredited National Scientific Journals, International Scientific Journals, and Reputable International Scientific Journals. The results of the study reveal that Islamic banking has positive productivity growth, based on the area of Islamic Banking outside the Gulf Cooperation Council (GCC), has better performance. Sharia Banking in the Southeast Asia Region, represented by Malaysia and Indonesia, alternately, received the best ranking based on the ranking by the Islamic Finance Country Index (IFCI).

Keywords: Malmquist Index; Islamic Banking Performance.
\end{abstract}

How to Cite: Supriyanto, Fachrudin, K.A., Octavianus, H., Meliza, J., Hastalona, D., \& Taslim, (2021). Indeks Malmquist: Studi Literatur dan Kajian Kinerja Perbankan Syariah. Journal of Education, Humaniora and Social Sciences (JEHSS). 4 (2): 1257-1265. 


\section{PENDAHULUAN}

Konversi sistem keuangan konvensional menjadi sistem keuangan syariah merupakan sebuah implementasi keinginan dan harapan dari $24,91 \%$ populasi penduduk dunia yang merupakan muslim. Sesuai ulasan Yasmin (2020), terungkap bahwa jumlah penduduk dunia sebanyak 7.657.330.000 orang dengan jumlah penduduk muslim sebanyak 1.907.110.000 orang. Mempertimbangkan besaran populasi tersebut, maka potensi Keuangan Syariah (Islamic Finance), terutama potensi Perbankan Syariah (Islamic Banking) secara matematis tentunya sangat besar. Namun demikian yang menjadi pertanyaan adalah berapa banyak negara yang sudah memiliki Bank Syariah?, berapa banyak jumlah Perbankan Syariah?, berdasarkan jumlah yang ada tersebut bagaimana kinerjanya?.

Islamic Finance Country Index (2020) mengungkapkan bahwa dari 193 negara yang diakui oleh Perserikatan Bangsa Bangsa (PBB), terdapat 48 negara yang sudah memiliki perbankan Syariah, berdasarkan pemeringkatan yang dibuat Islamic Finance Country Index (IFCI), secara keseluruhan Malaysia tahun 2020 menuduki peringkat satu, dengan skor 83,33, yang menyalip Indonesia yang pada tahun lalu berada pada peringkat satu, Malaysia mendominasi peringkat tersebut sejak 2011, sedangkan negara-negara Timur Tengah paling tinggi pada peringkat tiga. Kondisi ini menjadi menarik, ternyata kinerja Keuangan Syariah termasuk Perbankan Syariah tidak didominasi oleh negara-negara Timur Tengah yang secara de facto dan kultural merupakan sumber keuangan syariah. Kinerja perbankan Syariah suatu negara merupakan akumulasi kinerja perbankan syariah secara individu. Kinerja Perbankan Syariah diperlukan suatu pengukuran yang tepat terutama pada faktor efisiensi dan produktivitasnya.

Bank Syariah merupakan Lembaga keuangan yang mengedepankan konsep bagi hasil serta margin yang sesuai dengan prinsip Syariat Islam, pertumbuhan unit bisnis maupun asset perbankan Syariah ternyata sangat mengembirakan terutama di negara-negara yang penduduknya mayoritas Muslim seperti di Indonesia, Pakistan dan Malaysia, bahkan di negara yang Muslim sebagai kelompok yang minoritas seperti di Thailand, Singapura dan Filipina. Diwakili oleh Indonesia dan Malaysia, menjadikan Asia Tenggara sebagai kawasan yang cukup pesat perkembangan perbankan syariahnya, dibandingkan kawasan lain yang secara tradisional merupakan kawasan yang mayoritas penduduknya muslim antara lain Timur Tengan dan Afrika Utara. Memepertimbangan fenomena tersebut, studi tentang efisiensi dan produktivitas perbankan Syariah sudah cukup banyak dilakukan baik yang bersifat domestik maupun internasional, sehingga cukup relevan untuk dilakukan studi literatur dan kajian dengan obyek perbankan Syariah yang dilakukan oleh peneliti sebelumnya.

\section{METODE PENELITIAN}

Metode penelitian yang digunakan adalah studi pustaka atau studi literatur, Nazir (2011) menyatakan bahwa studi Pustaka merupakan teknik pengumpulan data dengan mengadakan studi penelaah terhadap buku-buku, literatur-literatur, catatan-catatan, dan laporan-laporan yang ada hubungannya dengan masalah yang dipecahkan. Selanjutnya Sugiyono (2017) menyatakan bahwa studi kepusatakaan merupakan langkah yang penting dimana setelah seseorang peneliti menetapkan topik penelitian, langkah selanjutnya adalah melakukan kajian teoritis dan referensi yang terkait dengan penelitian yang dilakukan.

Pada penelitian ini difokuskan pada literatur-literatur yang memiliki relevansi dengan tujuan penelitian, berupa Jurnal Ilmiah baik Jurnal Ilmiah Nasional, Jurnal Ilmiah Nasional Terakreditasi, Jurnal Ilmiah Internasional dan Jurnal Ilmiah Internasional Bereputasi yang membahas tentang kinerja perbankan Syariah yang menggunakan metode Indeks Malmquist. Dengan pertimbangan dan kriteria tersebut maka ditetapkan sebanyak 12 artikel ilmiah di Jurnal Jurnal Ilmiah baik Jurnal Ilmiah Nasional, Jurnal Ilmiah Nasional Terakreditasi, Jurnal Ilmiah Internasional dan Jurnal Ilmiah Internasional Bereputasi. 


\section{HASIL DAN PEMBAHASAN}

Pada tabel 1 disajikan berbagai literatur yang melakukan kajian produktivitas pada perbankan Syariah yang menggunakan Indeks Malmquist

Tabel 1. Hasil Penelitian Indeks Malmquist

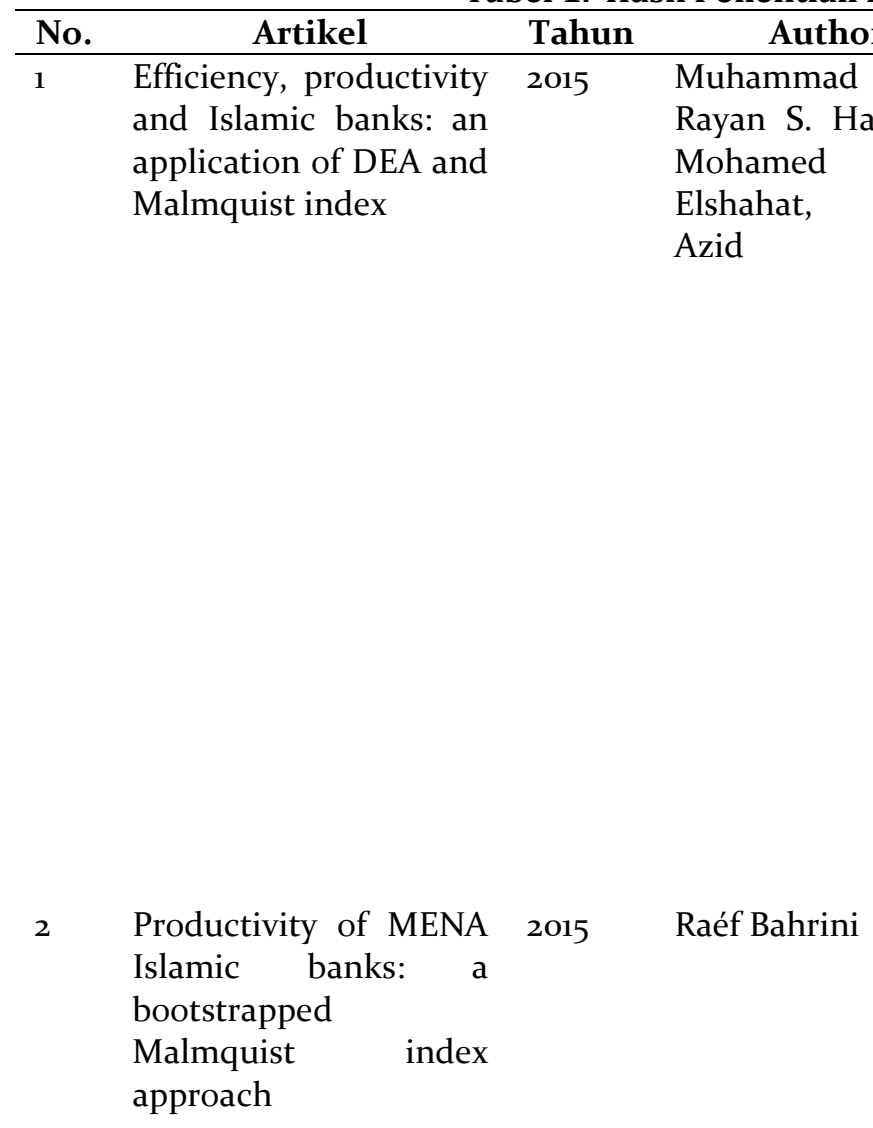

Hasil Penelitian

and Islamic banks: an application of DEA and Malmquist index
3 Testing The Effects of 2015 BRSA on Turkish Banking Sector by Malmquist Index (19952010)
Orhan Çoban. Pada penelitian ini, pembentukan BRSA Fatma Nur sebagai regulator, pengaruhnyanya Yorgancilar, Esra terhadap Total Factor Productivity diukur Kabaklarli dengan indeks Malmquist Hasil penelitian mengungkapkan bahwa produktivitas Perbankan Turki mengalami peningkatan setelah pembentukan Banking Regulation and Supervision Agency's (BRSA), hasil analisis menunjukkan bahwa TFP menurun sebesar $0,5 \%$ pada periode pra- 
Does productivity of 2017

Islamic banks endure progress or regress?

Empirical evidence using data envelopment analysis based Malmquist Productivity Index
Fakarudin

Kamarudin, Chiun Zack Hue, Fadzlan

Sufian, Nazratul

Aina Mohamad

Anwar

regulasi, setelah regulasi, terjadi peningkatan TFP sebesar 2,2\%.

Penelitian bermaksud untuk mengungkapkan dampak serta interaksi yang mempengaruhi tingkat kinerja Perbankan Syariah bank di Brunei, Indonesia dan Malaysia selama periode 2006-2014 dengan menggunakan Metode MPI berbasis DEA melalui pengukuran tingkat produktivitas. Hasil penelitian mengyungkapkan bahwa :

(1) Bank Syariah Internasional lebih produktif dibandingkan dengan Bank Syariah Domestik, efficiency change (EFFCH) lebih tinggi tetapi tidak berbeda secara signifikan.

(2) Kapitalisasi, likuiditas dan faktor penentu krisis keuangan berpengaruh secara signifikan terhadap tingkat produktivitas Bank Syariah.

Performance and 2018 Productivity in Islamic and Conventional Banks: Evidence from the Global Financial Crisis
Productivity of Islamic and Conventional Banks in Malaysia During The Pre And
Christos Alexakis, Jill Johnes, Marwan Izzeldin, Vasileios Pappas

Penelitian ditujukan guna menilai kinerja dan produktivitas bank syariah dan konvensional di kawasan Gulf Cooperation Council (GCC) dengan menggunakan rasio keuangan melalui dua dan empat komponen indeks produktivitas Malquist periode pengamatan 2006-2012. Hasil penelitian menemukan bahwa bank syariah menunjukkan kinerja biaya dan laba yang kurang baik tetapi setara dalam hal kinerja pendapatan dibandingkan dengan yang konvensional. Komponen dari indeks produktivitas Malquist merekomendasikan bahwa teknologi bank konvensional meningkat tajam terutama pada tahun menjelang krisis keuangan global, kemudian mengalami penurunan, sedangkan Bank syariah menunjukkan pola yang serupa dengan Bank Konvensional namun tidak lebih ekstrim. Secara keseluruhan, analisis indeks produktivitas Malquist menunjukkan bahwa kedua bank, baik Bank Syariah maupun Bank Konvensional lebih selaras setelah krisis keuangan global.

Muhamad Azhari Penelitian ini bertujuan untuk melakukan Wahid, Mohd evaluasi dan membedakan perubahan Shukor Harun produktivitas 17 bank syariah Malaysia dan 21 bank konvensional pada masa sebelum dan setelah krisis keuangan mahesainstitut@gmail.com 
Post Global Financial

Crisis
The efciency of Islamic Banks in the Southeast Asia (SEA) Region

global. Krisis keuangan global mendorong perlambatan pertumbuhan aset, simpanan, dan pinjaman sector perbankan Malaysia, kondisi tersebut dapat mempengaruhi produktivitas bank Malaysia baik Bank Syariah maupun Bank konvensional. Guna memperkirakan perubahan produktivitas total kedua jenis bank tersebut, penelitian ini menggunakan metode Malmquist Productivity Index (MPI). Dalam menghitung MPI, mempertimbangkan total simpanan, beban pegawai dan aset tetap sebagai input sedangkan untuk output, mempertimbangkan pinjaman, investasi dan pendapatan non-bunga.

(1) Secara empiris terungkap bahwa bank syariah dan konvensional produktif secara kinerja, namun hasil menunjukkan bahwa bank syariah lebih produktif dibandingkan dengan bank konvensional.

(2) Menariknya, bahwa baik bank syariah maupun konvensional telah gagal beroperasi pada skala operasi yang optimal, yang berdampak negatif pada tingkat produktivitas bank-bank tersebut.

(3) Krisis keuangan global berdampak negatif pada tingkat produktivitas Bank Syariah dan Bank Konvensional di Malaysia.

2021

Mohammad Abdul Matin Chowdhury, Razali Haron
Perbankan syariah Asia Tenggara menjadi bagian penting dari industri perbankan global, perbankan Syariah mengalami pertumbuhan yang menggembirakan, namun sebagian besar penelitian fokus pada efisisensi bank Syariah di masingmasing negara, sehingga untuk kesenjangan literatur, maka penelitian ditujukan untuk mengukur efisiensi dan produktivitas pertumbuhan bank syariah di kawasan Asia Tenggara. Penelitian mengadopsi teknik DEA dan produktivitas Malmquist indeks untuk mengevaluasi kinerja 31 bank syariah di Asia Tenggara dari 2014 hingga 2019. Hasil penelitian mengungkapkan bahwa terdapat peningkatan efisiensi dan produktivitas pada bank-bank di Asia Tenggara. Efisiensi dan produktivitas Bank Syariah di Indonesia lebih baik dibandingkan dengan negara-negara lain di ASEAN, efisiensi yang konsisten untuk 
8

The sources of
productivity change
and efficiency in
Islamic banking:
Application of
Malmquist productivity
index

Efficiency Analysis of 2007 Islamic Banks in Africa, Asia and the Middle East

Measuring of Islamic Banking Productivity in Indonesia Using Malmquist Index
Malaysia, perkembangan yang baik untuk Brunei, sedangkan pada tahun 2019 Bank Syariah Thailand dan Filipina menunjukkan penurunan efisiensi.

Artikel ini bertujuan untuk mengungkapkan kinerja bank syariah di 13 negara dengan periode pengamatan mulai tahun 2005 hingga tahun 2014 dan meniliti sumber perubahan produktivitas dari waktu ke waktu, penelitian menguraikan indeks produktivitas Malmquist menjadi 3 (tiga) komponen, yaitu perubahan efisiensi teknis, perubahan teknologi, dan perubahan efisiensi skala, yang dapat menentukan sumber peningkatan atau penurunan produktivitas bank syariah. Hasil penelitian mengungkapkan bahwa Bank syariah cukup produktif dan, tetapi belum mencapai skala efisien dan sangat terkendala dengan perubahan teknologi. Selain itu, diketahui bahwa krisis subprime berdampak negatif terhadap produktivitas perbankan syariah.

Viverita, Kym Penelitian ditujukan untuk mengkaji Brown, Michael tentang perubahan atau peningkatan Skully efisiensi Syariah bank menggunakan Metode Malmquist DEA pada kurun waktu tahun 1998 hingga - 2002 berdasarkan negara dan regional. Hasil penelitian menyatakan bahwa Asia menjadi kawasan bank Syariah dengan kinerja terbaik, sedangkan pada tingkat negara, Indonesia dan Yaman diketahui sebagai negara yang paling maju dengan kinerja terbaik. Uni Emirat Arab dan wilayah Timur Tengah, memiliki penggunaan input dan output terbaik pada perubahan efisiensi. Perubahan efisiensi dan perubahan TFP berhubungan negatif dengan umur bank.

2019 Irman Firmansyah Penelitian ditujukan untuk mengukur produktivitas Bank Syariah di Indonesia pada periode 2013 sampai dengan 2017, dengan menggunakan Indeks Produktivitas Malmquist. Pada tahun 2014 merupakan periode produktif bank syariah di Indonesia. Bank yang paling tinggi peningkatkan produktivitas adalah Bank Muamalat diikuti oleh Bank Syariah Mandiri, sedangkan Bank Viktoria mengalami penurunan produktivitas paling besar. 
11

$\begin{array}{lrl}\text { Indeks } & \text { Malmquist } & 2018 \\ \text { untuk } & \text { Pengukuran } & \\ \text { Efisiensi dan } & \\ \text { Produktivitas } \quad \text { Bank } & \\ \text { Syariah Di Indonesia }\end{array}$

\section{Aam Rusydiana}

Produktivitas Bank

Syariah Di Indonesia
Slamet Analisis data menggunakan teknik Malmquist Productivity Index (MPI) ditujukan mengukur tingkat produktivitas dana sosial pada 8 (delapan) Bank Umum Syariah (BUS) periode 2013 2017, dengan menggunakan variabel input adalah penerimaan dana zakat dan dana kebajikan, sedangkan variabel outputnya adalah penggunaan dana zakat dan dana kebajikan. Skor indeks Malmquist (TFP Change) menunjukkan bahwa 8 bank syariah dari total 11 BUS mengalami peningkatan produktivitas, atau sekitar $73 \%$ dari keseluruhan bank umum syariah. Pada analisis kelompok bank dengan kriteria efficiency change (EFFCH) dan technological change (TECH), terdapat 1 BUS berada pada kuadran 1, (technical change dan efficiency change yang tinggi), 4 bank syariah yang berada pada kuadran 2 (technical change yang tinggi namun efficiency change rendah), dan 6 bank syariah yang masuk ke dalam kuadran 3 (technical change rendah namun efficiency change yang tinggi). Sementara itu tidak ada satu pun bank umum syariah yang masuk kategori kuadran 4 .

Fenomena perbankan dan keuangan syariah telah berkembang secara signifikan dalam beberapa tahun terakhir, penelitian ditujukan untuk memberikan bukti empiris baru tentang kinerja Bank Syariah di Malaysia selama periode 20012004. Kontribusi penelitianini setidaknya meliputi tiga bidangm, (1) Menjadi studi pertama yang meneliti produktivitas relatif antara Bank Syariah Domestik dengan bank Bankan Syariah Internasional, (2) Intensifikasi persaingan diantara bank domestik dan asing di Malaysia, mendorong Pemerintah Malaysia untuk meliberalisasi sistem perbankan, (3) Tumbuhnya kesadaran di kalangan orang Malaysia tentang produk dan layanan keuangan Islam, yang membuat pentingnya masalah efisiensi dan produktivitas baik dari pembuat kebijakan dan pandangan publik.

Metode yang digunakan adalah Indeks Produktivitas Malmquist (MPI), dengan menggunakan 5 (lima) indikator yang terdiri dari perubahan produktivitas 
(TFPCH), perubahan teknologi (TECHCH), perubahan efisiensi (EFFCH), perubahan efisiensi teknis murni (PEFFCH) dan skala indeks perubahan efisiensi (SECH). Hasil penelitian menunjukkan bahwa produktivitas bank syariah Malaysia diketahui memilki perilaku berbentuk $U$ terbalik, dengan produktivitas sebesar $8,4 \%$ pada tahun 2002, selanjutnya meningkat dengan mencatat produktivitas tertinggi sebesar $11,2 \%$ pada tahun 2003, kemudian menurun menjadi sebesar $4,6 \%$ pada tahun 2004. Hasil penelitian mengungkapkan bahwa Bank Syariah Domestik menunjukkan pertumbuhan produktivitas yang lebih tinggi dibandingkan dengan Bank Syariah Internasional.

Sumber: Rangkuman Berbagai Sumber, 2021.

\section{SIMPULAN}

Malmquist Productivity Index (MPI) dalam menguji produktivitas perbankan, baik Bank Syariah maupun Bank Konvensional yang membutuhkan variabel yang lebih dari satu, agar diperoleh hasil analisis yang lebih baik. Penelitian yang menggunakan Metode Malmquist sebaiknya menggunakan beragam input maupun output. Indeks Malmquist selain digunakan untuk mengukur tingkat produktivitas perbankan, juga dapat digunakan untuk menganalisis perubahan kinerja perbankan, baik Bak Syariah maupun Bank Konvensional dari waktu ke waktu. Berdasarkan kajian dari 12 artikel ilmiah tersebut, setelah dikelompokkan ke dalam 3 (tiga) sub kajian yang terdiri dari (1) Wilayah Operasional Bank Syariah, (2) Periode waktu pengambilan data serta (3) Perbandingan dengan Bank Kovensional, dapat diketahui bahwa berdasarkan wilayah operasional perbankan Syariah yang diteliti diketahui bahwa kinerja perbankan Syariah mengalami fluktuasi, namun secara umum kinerja perbankan Syariah cukup baik terutama Bank Syariah di Kawasan Asia Tenggara, selanjutnya merujuk pada periode waktu pengambilan data, pada rentang waktu tahun 1998 - 2017, diketahui bahwa produktivitas perbankan Syariah mengalami pertumbuhan yang cukup baik, meskipun mengalami penurunan pada saat krisis keuangan global. Apabila dibandingkan dengan kinerja Bank Konvensional, dapat diasumsikan bahwa kinerja perbankan Syariah relative lebih baik.

\section{DAFTAR PUSTAKA}

Abbas, M., Hammad, R. S., Elshahat, M. F., \& Azid, T. (2015). Efficiency, productivity and Islamic banks: an application of DEA and Malmquist index. Humanomics.

Alexakis, C., Izzeldin, M., Johnes, J., \& Pappas, V. (2019). Performance and productivity in Islamic and conventional banks: Evidence from the global financial crisis. Economic Modelling, 79, 1-14.

Bahrini, R. (2015). Productivity of MENA Islamic banks: a bootstrapped Malmquist index approach. International Journal of Islamic and Middle Eastern Finance and Management.

Çoban, O., Yorgancilar, F., \& Kabaklarl,, E. (2015). Testing The Effects of Brsa on Turkish Banking Sector By Malmquist Indeks (1995-2010). Niğde Üniversitesi İktisadi ve İdari Bilimler Fakültesi Dergisi, 8(2), 121-141.

Chowdhury, M. A. M., \& Haron, R. (2021). The efficiency of Islamic Banks in the Southeast Asia (SEA) Region. Future Business Journal, 7(1), 1-16.

Firmansyah, I. (2019, July). Measuring of Islamic Banking Productivity in Indonesia Using Malmquist Index. In 1st International Conference on Life, Innovation, Change and Knowledge (ICLICK 2018) (pp. 251254). Atlantis Press. 
Ganouati, J., \& Essid, H. (2017). The sources of productivity change and efficiency in Islamic banking: Application of Malmquist productivity index. The Central European Review of Economics and Management, 1(4), 35-68.

Islamic Finance Country Index (2020). Global Islamic Finance Report 2020

Kamarudin, F., Hue, C. Z., Sufian, F., \& Anwar, N. A. M. (2017). Does productivity of Islamic banks endure progress or regress?. Humanomics.

Nazir, M. (2011). Metode Penelitian, Cetakan Ke Tujuh. Bogor: Penerbit Ghalia Indonesia.

Rusydiana, A. S. (2018). Indeks Malmquist untuk Pengukuran Efisiensi dan Produktivitas Bank Syariah Di Indonesia Malmquist Index To Measure The Efficiency And Productivity Of Indonesia Islamic Banks. Jurnal Ekonomi dan Pembangunan, 26(1).

Sugiyono. (2017). Metode Penelitian Kuantitatif, Kualitatif, Dan R\&D. Bandung: Alfabeta.

Sufian, F. (2007). Malmquist Indices Of Productivity Change In Malaysian Islamic Banking Industry: Foreign Versus Domestic Banks. Journal Of Economic Cooperation Among Islamic Countries, 28(1).

Viverita, K. B., \& Skully, M. (2007). Efficiency analysis of Islamic banks in Africa, Asia and the Middle East. Review of Islamic Economics, 11(2), 5-16.

Wahid, M. A., \& Harun, M. S. (2019). Productivity of Islamic and Conventional Banks in Malaysia During the Pre and Post Global Financial Crisis. The Journal of Muamalat and Islamic Finance Research.

Yasmin, P. https://news.detik.com/berita/d-5279850/agama-terbesar-di-dunia-2020-berdasarkan-jumlahpemeluknya. 